\title{
Minimum tillage practices affect disease and yield of lettuce
}
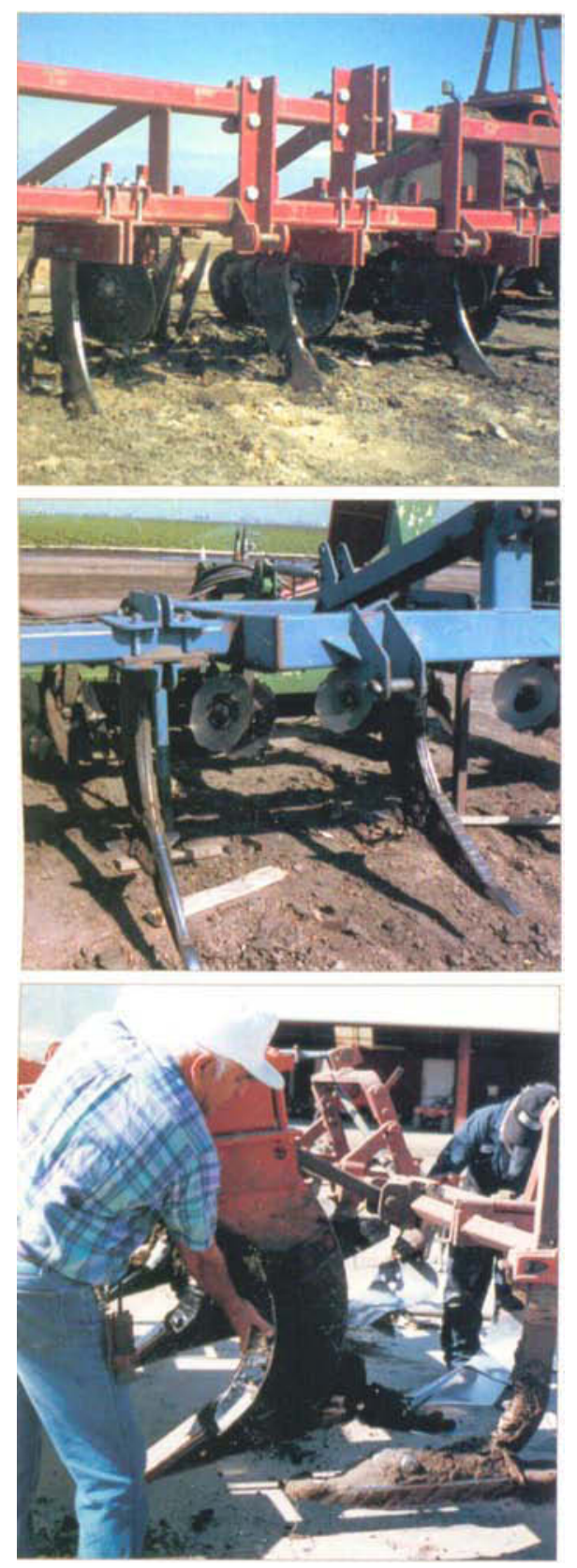

The authors compared lettuce reducedtillage systems for their effects on soil organic matter, compaction, yield and disease, including, top to bottom: the Sundance System for shallow minimum tillage; the minimum-till chisel, for deep minimum tillage; and the minimum-till ripper, part of a four-step deep minimum tillage program designed by Chualar grower Israel Morales (shown). All three treatments retain semipermanent beds.

\author{
Louise E. Jackson Irenee R. Ramirez \\ Israel Morales - Steven T. Koike
}

retention of semipermanent, raised beds in lettuce production. Over a period of several years, deep minimum tillage increased lettuce yield and decreased symptoms of lettuce drop disease, as compared with shallow minimum tillage. Continuous shallow minimum tillage, despite a trend toward higher active and total organic matter in the surface layer of soil, is best used with intermittent deeper tillage to avoid disease and yield losses. 'illage is known to decrease soil
organic matter, including the active fraction that is largely composed of microbial cells. Soil organic matter is beneficial for nutrient cycling, water infiltration, and in some cases, disease suppression. Tillage can also cause soil compaction of deeper layers of the soil profile, especially in soils that are tilled when wet, as can often occur in vegetable crop systems. Compaction impedes the growth of roots into deep soil layers, restricting the plant's acquisition of water and nutrients. Recently, reduced or minimum tillage in vegetable crop systems has attracted attention as a possible means of increasing soil organic matter and decreasing labor and production costs.

In the Salinas Valley, cool-season vegetables such as lettuce, cole crops and celery are farmed year-round. Most of these crops return little organic matter to the soil after harvest, and soil organic matter has declined markedly during the last century (Wyland et al. 1996). Conventional tillage occurs frequently and intensively, ranging from single passes with culti- vators for weed control, to ripping, disking and leveling fields between crops. Conventional disking inverts and mixes the soil to a depth of 6 to 10 inches, while ripping penetrates 15 to 20 inches.

Innovative tillage techniques are being developed for vegetable production. At one extreme are no-tillage systems, in which crop residues are left on the soil surface and little soil disturbance occurs. Another option, which is examined here, is to retain semipermanent, raised beds for multiple crop seasons. California vegetable growers often call this reduced tillage or minimum tillage, even though it does not leave significant amounts of plant residue on the soil surface. Growers retain beds to reduce time, fuel and labor costs that accrue from disking and reshaping beds between each crop. We tested the hypothesis that the use of semipermanent beds and minimum tillage may also be beneficial in reducing soil compaction and increasing total organic matter and soil microbial biomass, which serves as a measure of the active fraction of soil organic mat- 


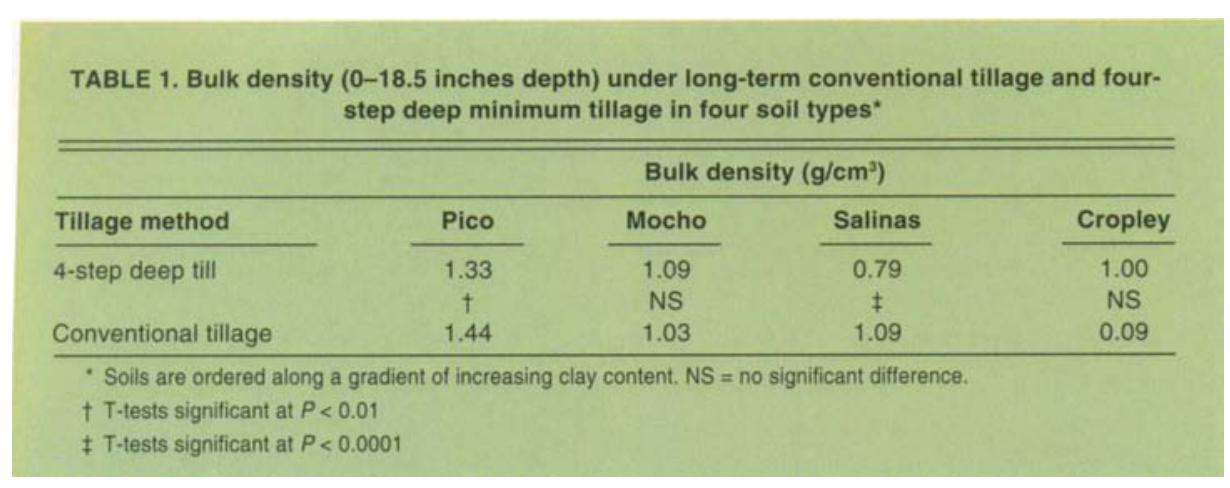

ter. A concern, however, was that disease severity might increase with minimum-tillage methods that till only the surface soil, because of the accumulation of propagules of soil disease organisms. Lettuce drop disease (Sclerotinia minor) is of particular interest because some scientists have found a higher incidence with subsurface drip irrigation and associated mandatory minimum tillage (Bell et al. 1998).

\section{Types of minimum tillage}

Shallow minimum tillage refers to operations such as the Sundance System, a brand-name tillage implement that uses disks and lister bottoms (a kind of shovel) to incorporate crop residues and cultivate the tops and sides of the beds in a single pass. This method tills shallowly (approximately 6 to 8 inches) so that subsurface drip irrigation can be used. Deep minimum tillage, in contrast, is intended to also reduce soil compaction. A minimumtill chisel is designed to simultaneously chisel the furrows to approximately 20 inches in depth with a narrow shank, and disk hill the soil into peaked beds. Another option for deep minimum tillage consists of four tillage operations, which each require one pass consecutively with different implements: the minimum-till chisel; the Sundance System; the minimum-till ripper, which uses angled, broad shanks with floating wings to break the compacted layer across the beds at depth; and finally, a surface rototill/mulcher to smooth the surface and prepare a seedbed. This four-step method, designed by a Salinas Valley grower, requires 1.5 to 2 hours per acre, retains semipermanent beds and tills the soil to approximately 20 inches in depth.
We conducted an on-farm project to evaluate these minimum-tillage options for lettuce production in the Salinas Valley. Farmers' fields offer the opportunity to study alternative management practices under realistic soil conditions, pest pressure and marketing constraints. There are, however, some drawbacks. Farmers are not always able to include control plots or management practices that have potentially detrimental effects on yield, nor are they always willing to spend extra management efforts on truly replicating treatments.

In this project, we had three objectives for studying alternative tillage practices in an on-farm environment. First, we assessed soil bulk density to determine soil compaction on neighboring fields that had been in longterm management with either four-step deep minimum tillage or typical, conventional tillage (disking across, then remaking beds between every crop). Second, we measured the effects of a single episode of intensive conventional tillage (deep chiseling, ripping and laser planing) on a field that had been under long-term management with four-step deep minimum tillage. Third, we compared deep and shallow minimum-tillage practices for effects on soils, crop yield and crop disease symptoms for 3 years.

\section{Compaction on four soil types}

We compared soil bulk density in fields that had been farmed for at least 5 years with four-step deep minimum tillage retaining semipermanent beds, and in fields under a regime of conventional tillage in which beds were remade between every crop. All fields were managed with sprinkler and furrow irrigation, and planted with coolseason vegetables (e.g., lettuce, cole crops and spinach). We chose fields that were in adjacent lots of the same soil type. The soil types were Pico fine sandy loam, Mocho silt loam, Salinas clay loam and Cropley silty clay. Each set of sampling points was less than 110 yards apart. The samples were taken just before the first spring tillage event in 1998 to eliminate the effect of recent management practices.

Cylinders (20-inch-deep sections of 4-inch-diameter PVC pipe, schedule 40) were driven into the center of the beds to a depth of 18.5 inches. Three cores were removed per sampling site. Soil was removed, dried and weighed to calculate bulk density as grams dry soil per centimeter-cubed. (Multiply by 62.4 to obtain pounds per foot cubed.) Means were compared with t-tests, using the $P<0.05$ significance level.

For two soil types, Pico and Salinas, bulk density was significantly lower in the fields managed with deep minimum tillage. For the other two soil types, no significant differences were observed (table 1). These data indicate that compaction may decrease in some cases when beds are retained with the four-step deep minimum-tillaye operations as compared with conventional practices that disk and reshape beds between every crop.

\section{On-farm trial established}

An on-farm trial was established in September 1995 near Chualar, in the Salinas Valley. The soil was a Cropley

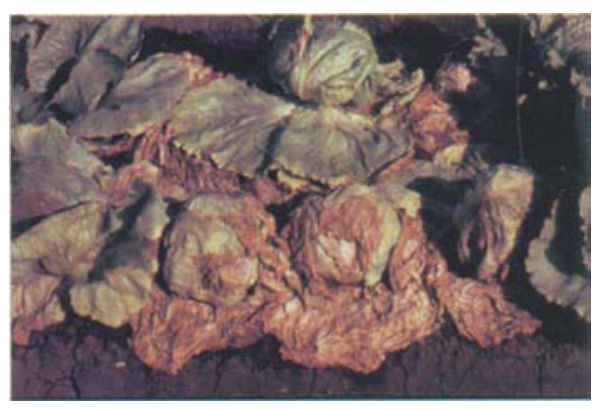

Scientists have found a higher incidence of lettuce drop disease (Sclerotinia minor) with subsurface drip irrigation and related tillage practices. 
silty clay composed of $5.7 \%$ sand, $50.7 \%$ silt and $43.6 \%$ clay. Total organic carbon and nitrogen were $2.19 \%$ and $0.22 \%$, respectively. The field had been in cool-season vegetable production using four-step deep minimum tillage for 3 years. In 1993, 1994 and 1995 , one broccoli and one crisphead lettuce crop were produced each year using sprinkler and furrow irrigation. Intensive conventional tillage of the field occurred between Nov. 20 and Dec. 12, 1995, as follows: disked two times, ripped two times, disked five times, chiseled two times, disked four times, laser leveled, chiseled two times and listed (shaped) into beds. The grower's purpose was to increase the uniformity of the field.

Soil samples were taken in September 1995, and again in February 1996. A 1.2-acre grid system of 12 points in a randomized complete block design was established so that each point could be sampled before and after the intensive conventional tillage operations. Soil cores were taken from the center of the beds at two depths, at 0 to 2.4 inches, where lettuce roots are abundant, and at 15.7 inches to 18.1 inches, where a compacted "plow pan" layer typically occurs. All soil samples were subsampled for gravimetric soil moisture content to determine changes in water retention. Net mineralizable nitrogen was measured to determine changes in potential nitrogen supplying power in the top soil layer, where most of the organic matter resides. A 7-day anaerobic incubation procedure was used. Bulk density samples were taken for each depth using brass rings of 3.4-inch diameter that were pounded into the soil. Treatment means were compared with t-tests $(P<0.05)$.

No significant difference in bulk density or net mineralizable nitrogen occurred between the fall and winter samples taken before and after intensive tillage and land planing on soil that had been under four-step deep minimum tillage for several years (table 2). Gravimetric moisture was also similar on both dates in the two layers, suggesting that little change in water-holding characteristics had occurred. These results suggest that a single episode of conventional tillage had little effect on these soil properties.

\section{Alternative tillage study}

To study the long-term effects of alternative tillage practices on soil properties, crop yield and lettuce diseases, the study area was managed for 3 years with shallow (Sundance System only) and deep (minimum-till chisel) tillage to retain semipermanent beds on strips of 21 yards by 220 yards (0.95-acre plots). These treatments began in April 1996, 4 months after the intensive ripping, disking and leveling operations described above. A third treatment, four-step deep minimum tillage, was done adjacent to these strips, but was not sampled until 1998. Thus, the study area was divided into three strips, with each strip receiving one of three treatments that retained semipermanent beds for the 3-year period: shallow minimum tillage, minimum-till chisel or four-step deep minimum tillage. These strips were each divided into three blocks, 21 yards by 73 yards each. Two samples were taken per block. The same points ( \pm 15 feet) were sampled on successive dates at six sampling points for each tillage treatment.

The field was managed uniformly with inorganic fertilizers and sprinkler and furrow irrigation. From 1996 through 1999, one broccoli and one crisphead lettuce crop were produced each year. A cover crop of was grown in the fall of 1998. The lettuce cultivar was Sharpshooter in 1997 and 1998, and Venus in 1999. Bulk density and

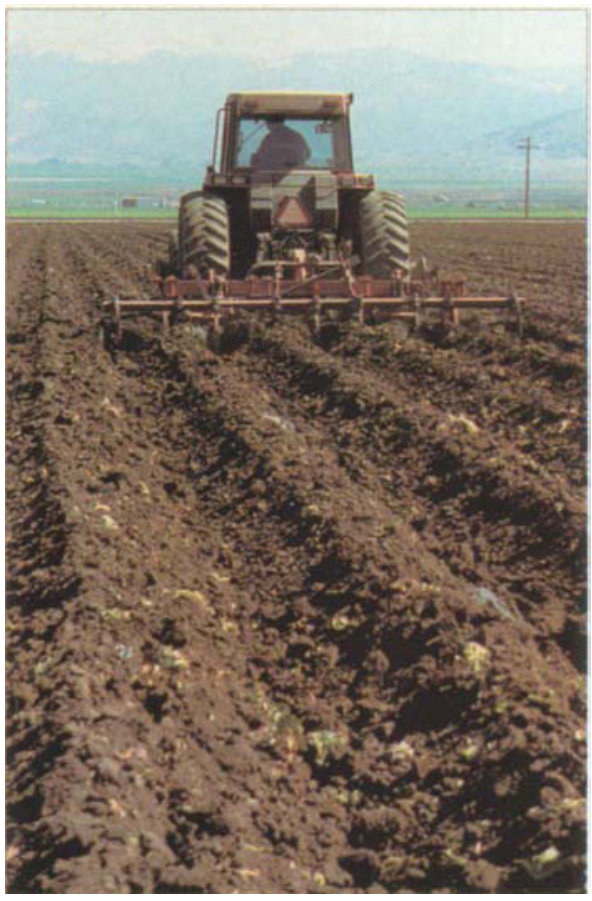

In a 3-year study, intermittent deep chiseling and ripping resulted in higher fresh lettuce yield and fewer symptoms of lettuce drop disease. A minimum-till ripper in the field undertakes the last step of the four-step deep minimum tillage program.

moisture were measured at depths of 0 to 2.4 inches, and 15.7 inches to 18.1 inches. In 1999, these were also measured at 7.9 inches to 10.2 inches in the middle of the lettuce rooting zone. Soil microbial biomass carbon was determined for the 0-to-4-inch depth. Total organic carbon and nitrogen were tested by combustion. Approximately 500 lettuce plants per sampling point were visually examined in the field for symptoms of lettuce drop disease. Mean percentage of the taproot showing cracking and yellowing characteristics of corky root disease (Rhizomonas suberfaciens) was

\begin{tabular}{|c|c|c|c|c|c|c|}
\hline \multirow[b]{2}{*}{$\begin{array}{l}\text { Depth } \\
\text { (inches) }\end{array}$} & \multicolumn{2}{|c|}{$\begin{array}{l}\text { Bulk density } \\
\left(\mathrm{g} / \mathrm{cm}^{3}\right)\end{array}$} & \multicolumn{2}{|c|}{$\begin{array}{c}\text { Net mineralizable } N \\
\left(\mu \mathrm{g} \mathrm{N} / \mathrm{g}^{1} \text { dry soil) }\right.\end{array}$} & \multicolumn{2}{|c|}{$\begin{array}{c}\text { Soil gravimetric } \\
\text { moisture (\%) }\end{array}$} \\
\hline & $\begin{array}{l}\text { Sept } \\
1995\end{array}$ & $\begin{array}{l}\text { Feb } \\
1996\end{array}$ & $\begin{array}{l}\text { Sept } \\
1995\end{array}$ & $\begin{array}{c}\text { Feb } \\
1996\end{array}$ & $\begin{array}{l}\text { Sept } \\
1995\end{array}$ & $\begin{array}{l}\text { Feb } \\
1996\end{array}$ \\
\hline $0-2.4$ & 1.06 & 1.05 & 8.1 & 14.3 & 32.0 & 34.5 \\
\hline $15.7-18.1$ & 1.21 & 1.13 & ND & ND & 32.2 & 34.5 \\
\hline
\end{tabular}


TABLE 3. Responses to alternative tillage practices to retain semipermanent, raised beds*

\begin{tabular}{|c|c|c|c|c|c|c|c|c|}
\hline & \multicolumn{3}{|c|}{ July $1997 \dagger$} & \multicolumn{2}{|c|}{ July 1998} & \multicolumn{3}{|c|}{ Sept 1999} \\
\hline & Shallow & $\begin{array}{l}\text { Deep } \\
\text { chisel }\end{array}$ & Shallow & $\begin{array}{l}\text { Deep } \\
\text { chisel }\end{array}$ & $\begin{array}{l}\text { 4-step } \\
\text { deep till }\end{array}$ & Shallow & $\begin{array}{l}\text { Deep } \\
\text { chisel }\end{array}$ & $\begin{array}{l}\text { 4-step } \\
\text { deep till }\end{array}$ \\
\hline \multicolumn{9}{|c|}{ Lettuce yield and disease } \\
\hline $\begin{array}{l}\text { Fresh weight }(\mathrm{g}) \\
\text { Dry weight }(\mathrm{g}) \\
\text { Lettuce drop (\%) } \\
\text { Corky root } \\
(\% \text { of taproot affected) }\end{array}$ & $\begin{array}{c}\text { ND } \\
21.30 \mathrm{~m} \\
6 \mathrm{~m}\end{array}$ & $\begin{array}{c}\text { ND } \\
22.56 \mathrm{~m} \\
4 \mathrm{~m}\end{array}$ & $\begin{array}{c}811 a \\
36.44 a \\
5 a\end{array}$ & $\begin{array}{c}863 a b \\
37.81 a \\
2 b\end{array}$ & $\begin{array}{c}943 c \\
39.24 a \\
1 b\end{array}$ & $\begin{array}{c}873 x \\
36.46 x \\
4 x\end{array}$ & $\begin{array}{c}939 x y \\
38.85 x \\
2 y\end{array}$ & $\begin{array}{c}967 y \\
39.01 x \\
1 z\end{array}$ \\
\hline \multicolumn{9}{|c|}{ Soil microbial biomass ( $\mu \mathrm{g} \mathrm{C} / \mathrm{g}^{1}$ dry soil) in surface layer } \\
\hline $0-4$ inches & $225 m$ & $254 m$ & 291a & $233 a b$ & $182 b$ & $355 x$ & $343 x$ & $330 x$ \\
\hline \multicolumn{9}{|c|}{ Soil bulk density ( $\mathrm{g} / \mathrm{cm}^{3}$ dry soil) at three depths } \\
\hline $\begin{array}{l}0-2.4 \text { inches } \\
7.9-10.2 \text { inches } \\
15.7-18.1 \text { inches }\end{array}$ & $\begin{array}{c}1.08 \mathrm{~m} \\
\mathrm{ND} \\
1.29 \mathrm{~m}\end{array}$ & $\begin{array}{c}1.06 \mathrm{~m} \\
\mathrm{ND} \\
1.24 \mathrm{~m}\end{array}$ & $\begin{array}{c}0.95 a \\
\text { ND } \\
1.19 a\end{array}$ & $\begin{array}{l}0.98 \mathrm{a} \\
\text { ND } \\
1.23 \mathrm{a}\end{array}$ & $\begin{array}{l}0.95 \mathrm{a} \\
\text { ND } \\
1.27 \mathrm{a}\end{array}$ & $\begin{array}{c}0.90 x \\
1.09 x y \\
1.24 x\end{array}$ & $\begin{array}{l}0.86 x \\
1.17 x \\
1.14 x\end{array}$ & $\begin{array}{l}0.99 x \\
0.96 y \\
1.07 x\end{array}$ \\
\hline \multicolumn{9}{|c|}{ Soil gravimetric moisture $(\%)$ at three depths } \\
\hline $\begin{array}{l}0-2.4 \text { inches } \\
7.9-10.2 \text { inches } \\
15.7-18.1 \text { inches }\end{array}$ & $\begin{array}{c}27.5 \mathrm{~m} \\
\mathrm{ND} \\
30.9 \mathrm{~m}\end{array}$ & $\begin{array}{l}29.1 \mathrm{~m} \\
\mathrm{ND} \\
32.0 \mathrm{~m}\end{array}$ & $\begin{array}{c}34.7 \mathrm{a} \\
\text { ND } \\
36.1 \mathrm{a}\end{array}$ & $\begin{array}{c}31.2 a b \\
\text { ND } \\
34.2 a\end{array}$ & $\begin{array}{c}33.0 \mathrm{~b} \\
\mathrm{ND} \\
33.6 \mathrm{a}\end{array}$ & $\begin{array}{l}28.6 x \\
32.9 x \\
34.0 x\end{array}$ & $\begin{array}{l}28.0 x \\
30.9 x \\
30.5 y\end{array}$ & $\begin{array}{r}27.6 x \\
30.8 x \\
31.1 x y\end{array}$ \\
\hline \multicolumn{9}{|c|}{ Soil total organic $\mathrm{C}$ and $\mathrm{N}(\%)$} \\
\hline $\begin{array}{l}\text { Org. C (0-4 inches) } \\
\text { Org. N (0-4 inches) }\end{array}$ & $\begin{array}{l}\text { ND } \\
\text { ND }\end{array}$ & $\begin{array}{l}\text { ND } \\
\text { ND }\end{array}$ & $\begin{array}{l}\text { ND } \\
\text { ND }\end{array}$ & $\begin{array}{l}\text { ND } \\
\text { ND }\end{array}$ & $\begin{array}{l}\text { ND } \\
\text { ND }\end{array}$ & $\begin{array}{l}2.01 \mathrm{x} \\
0.24 \mathrm{a}\end{array}$ & $\begin{array}{l}1.94 \mathrm{x} \\
0.24 \mathrm{a}\end{array}$ & $\begin{array}{l}1.93 x \\
0.22 b\end{array}$ \\
\hline \multicolumn{9}{|c|}{$\begin{array}{l}\text { Treatments began in April 1996. Shallow }=\text { Sundance System only; deep chisel = minimum-till chisel only; } \\
4 \text {-step deep till }=4 \text {-step deep minimum tillage. ND = no data. Means with the same letter are not } \\
\text { significantly different. See text for sample sizes. } \\
\text { t Sampled prior to harvest maturity. }\end{array}$} \\
\hline
\end{tabular}

assessed on approximately 12 plants per sampling point dug to a depth of 7 inches. Lettuce yield was determined by weighing the fresh whole heads in a 1.2-square-yard (1-square-meter) area at each sampling point, then again after drying. Lettuce root length density was determined in September 1997, in soil cores taken at 0 to 4,4 to 8,8 to 12,12 to 16,16 to 20 and 20 to 30 inches below the soil surface. Roots were washed free of soil, and root length was measured on a root-length scanner. Treatment differences were evaluated with t-tests $(P<0.05)$.

In July 1997, approximately 1 year after the treatments had begun, there were no differences in lettuce dry weight, disease symptoms, soil microbial biomass carbon, soil bulk density or gravimetric moisture between the shallow minimum tillage and minimum-till chisel treatments (table 3). Root-length distribution was also similar between treatments in all depth increments (data not shown). In this time interval, shallow and deep methods to retain semipermanent beds had similar effects.

In 1998, lettuce fresh weight was significantly lower in both the shallow and chisel minimum-tillage treatments than with four-step deep minimum tillage (table 3 ). There were no differences among treatments in lettuce dry weight. A higher percentage of lettuce plants had symptoms of lettuce drop wilt in the shallow minimum-tillage treatment than either of the deeper tillage treatments. The mean percentage of the taproot showing cracking and yellowing characteristics of corky root disease was significantly higher in the shallow treatment. Soil microbial biomass carbon in the surface layer was significantly higher for both the shallow and chisel minimum-tillage treatments than with four-step deep minimum tillage. Water content at the soil surface was highest in the shallow minimum-tillage treatment, intermediate in the four-step deep minimum treatment and lowest with chisel minimum tillage, suggesting slight differences in soil physical properties. No difference in bulk density was found among the tillage treatments.

In 1999, lettuce fresh weight was again lowest in the shallow minimumtillage treatment, intermediate in the minimum-till chisel treatment and highest with four-step deep minimum tillage (table 3). Dry-weight differences were again not significant among treatments. Reasons for the differences in lettuce fresh- and dryweight responses are not clear, but deserve further study. The percentage of plants with lettuce drop symptoms was higher with shallow minimum tillage than with minimum-till chisel, or with four-step deep minimum tillage. Corky root symptoms were minor, and no differences were observed, but 'Venus' is a corky root-resistant variety. Soil microbial biomass carbon was not significantly different between treatments. The cover crop in the previous winter may have contributed to higher levels and less difference between treatments compared with 1998. There were no significant differences among treatments in total organic carbon in the surface 4 inches of soil. Total organic nitrogen was significantly lower with four-step deep minimum tillage. Soil bulk density was similar among treatments at the surface and lowest depths, but was significantly lower with the four-step deep minimum tillage at the middle depth. Moisture at the lowest depth was highest for the shallow minimumtillage treatment.

\section{Plant vs. soil responses}

This on-farm project showed that minimum-tillage operations that include deep chiseling and ripping lead to higher fresh lettuce yield and lower symptoms of lettuce drop disease than the shallow minimum-tillage system, despite the trend toward decreased soil microbial biomass and organic matter in the surface layer when deep tillage was used. Deep tillage may bury sclerotia and thereby limit infection (UC IPM 1987). Higher yields with deep minimum tillage may be

(continued on back cover) 